To cite: L Chamberlain 'Assessing enabling rights: Striking similarities in troubling implementation of the rights to protest and access to information in South Africa' (2016) 16 African Human Rights Law Journal 365-384

http://dx.doi.org/10.17159/1996-2096/2016/v16n2a3

\title{
Assessing enabling rights: Striking similarities in troubling implementation of the rights to protest and access to information in South Africa
}

\section{Lisa Chamberlain*}

Deputy Director, Centre for Applied Legal Studies; Senior Lecturer, School of Law, University of the Witwatersrand, South Africa

\begin{abstract}
Summary
Many human rights have a dual value in that their realisation is both an important end, and a means to enable the realisation of other rights. The effective implementation of these kinds of rights is thus particularly important for advancing rights-based democracy. However, in practice, the implementation of such rights is often problematic. The article examines access to information and protest as examples of such 'enabling' rights. Drawing on the experience of communities and civil society organisations, it identifies and discusses some striking similarities in the way in which the legislation promulgated to give effect to these two rights in South Africa is being implemented, and argues that the problematic implementation of legislation is having the effect of thwarting these rights, rather than promoting them. Further, it argues that the existence of such striking similarities may point to a more systemic problem of civil and political rights failing to enable the realisation of socio-economic rights.
\end{abstract}

BA LLB (Witwatersrand) LLM (Michigan); lisa.chamberlain@wits.ac.za. I would like to thank my research assistant, Ashleigh Dore, for her useful assistance in putting this article together, as well as participants in the November 2014 New York Law School conference on 'Constitutional Rights, Judicial Independence and the Transition to Democracy: Twenty Years of South African Constitutionalism' for their helpful insights. The original idea for this article arose when I was sitting in various sessions of the 2014 Public Interest Law Gathering and was struck by the similar challenges faced by access to information activists and protesting communities. So thanks must also go to those who shared their experiences in that forum. 
Key words: access to information; protest; human rights; implementation of rights; Promotion of Access to Information Act; Regulation of Gatherings Act

\section{Introduction}

The rights of access to information and to protest are examples of 'enabling' rights which are valuable not just for their own sake, but also because they assist in the realisation of other rights. In South Africa, both are justiciable human rights, ${ }^{1}$ and legislation has been passed which fleshes out the nuts and bolts of how to go about exercising these rights. This legislation is the Promotion of Access to Information Act 2 of 2000 (PAIA) and the Regulation of Gatherings Act 205 of 1993 (Gatherings Act) respectively. Despite the very different contexts in which PAIA and the Gatherings Act were promulgated, their implementation bears striking similarities similarities which help us understand the limitations of rights realisation in the last two decades of democracy in South Africa. In both contexts, the very legal mechanisms designed to give effect to these rights are being administered in a way which undermines the rights themselves. The consequences are severe. If realising enabling rights, such as protest and access to information, is a precondition to the realisation of other rights, such as socio-economic rights and the right to dignity, then the South African democratic system is faltering at one of the first hurdles. Significantly, those most affected by the denial of these rights are South Africa's poorest communities.

The article explores these themes according to the following framework: by establishing the conceptual idea of 'enabling rights' and discussing protest and access to information in this context; setting out the characteristics of the applicable regulatory frameworks in South Africa; contrasting this theory with the practical reality of attempts by communities and civil society organisations to exercise the rights to protest and access to information; and, lastly, highlighting some striking parallels in these two areas of human rights law and practice, which suggest that both PAIA and the Gatherings Act serve to impede rather than advance human rights.

\section{Enabling rights}

\subsection{Idea of enabling rights}

Human rights discourse has long acknowledged the intersectionality of human rights in the sense that rights acquire meaning and content through the existence and realisation of other rights. The African Charter on Human and Peoples' Rights (African Charter) explicitly 
acknowledges that '[c]ivil and political rights cannot be dissociated from economic, social and cultural rights in their conception'. ${ }^{2}$ While many jurisdictions have been at pains to avoid establishing a hierarchy of rights, ${ }^{3}$ human rights are rarely violated in isolation and, therefore, the responses to rights violations should heed this intersectionality. ${ }^{4}$

One form that this intersectionality of rights can take is when the realisation of some rights is required for the realisation of other rights. The former category of rights may be referred to as 'enabling rights', given the fact that the realisation of these rights is a necessary precondition to the full enjoyment of other rights.

From the outset it must be acknowledged that enabling rights are valuable for their own sake. Staging a protest is an important exercise of agency, and at times getting hold of information is useful just because of a 'right to know'. More often, however, we seek to protest and obtain information because there is something further that we want to achieve by doing so. The existence of these enabling rights does not guarantee that the end sought (say, for example, the provision of a house) will materialise, but it does change the relationship between the parties by empowering the rights holder to demand certain things from the duty bearer. ${ }^{6}$

Second, it is important to note that the 'enabling' process can be multi-directional. For example, while the right to protest may be necessary in order to realise socio-economic rights, such as access to housing and adequate water, the realisation of rights such as the right

2 Preamble to the African Charter. In its own Preamble, the Principles and Guidelines on the Implementation of Economic, Social and Cultural Rights in the African Charter on Human and Peoples' Rights goes on to explain that the African Charter 'reflects that all human rights are indivisible, interdependent and interrelated, and cannot be enjoyed in isolation from each other'.

3 See eg the views of the South African Constitutional Court on this topic expressed in Khumalo \& Others $v$ Holomisa 2002 (5) SA 401 (CC) and MthembiMahanyele v Mail \& Guardian Ltd \& Another [2004] 3 All SA 511 (SCA) para 42.

4 Burke argues that despite the acknowledgment that human rights are indivisible and interdependent, the human rights sector 'lacks a unified approach to social, economic and cultural rights, on the one hand, and civil and political rights, on the other'. S Burke 'What an era of global protests says about the effectiveness of human rights as a language to achieve social change' (2014) 20 SUR International Journal on Human Rights 27.

5 See eg F Maupain 'Revitalisation not retreat: The real potential of the 1998 ILO Declaration for the Universal Protection of Workers' Rights' (2005) 16 European Journal of International Law 439 448, which discusses the idea of workers' rights as enabling the realisation of the rights to health and safety.

6 K Bentley \& R Calland 'Access to information and socio-economic rights: A theory of change in practice' in M Langford et al (eds) Socio-economic rights in South Africa: Symbols or substance? (2014) 347. 
to bodily integrity may, in turn, be necessary in order to unlock the exercising of the right to protest. 7

\subsection{Rights of access to information and to protest as enabling rights}

There are various rights which may be said to fall in the category of 'enablers'. The article focuses on the right to protest and the right of access to information. ${ }^{8}$ These two rights have been selected given noticeable parallels in the problematic way in which they are dealt with by government and the private sector in South Africa.

The notion of access to information as an enabling right is supported by the very language of section 32 of the South African Constitution, which makes a connection between access to information and the 'exercise or protection of any rights', at least in relation to information from private bodies. Bentley and Calland refer to access to information as both a 'power right' and a 'leverage right', $^{9}$ and articulate a theory of change which argues that the right of access to information can operate as a power lever to procure political space and, thereby, to claim socio-economic rights. ${ }^{10}$ In Brümmer v Minister for Social Development \& Others, the Constitutional Court confirmed that 'access to information is fundamental to the realisation of the rights guaranteed in the Bill of Rights' ${ }^{11}$

The same applies to protest, where the Constitutional Court acknowledged that the right to protest was central to South Africa's constitutional democracy as it exists primarily to give a voice to groups that do not have political or economic power. ${ }^{12}$ This right will, in many cases, be the only mechanism available to them to express

7 The Preamble to the African Charter recognises that 'the satisfaction of economic, social and cultural rights is a guarantee for the enjoyment of civil and political rights'. Similarly, the Preamble to the Principles and Guidelines on the Implementation of Economic, Social and Cultural Rights in the African Charter on Human and Peoples' Rights emphasises that 'the enjoyment of economic, social and cultural rights is not only imperative for but dependant on the enjoyment of civil and political rights'.

8 This 'enabling' quality of the right is implicit in the existence of legal instruments such as the Convention on Access to Information, Public Participation in Decision Making and Access to Justice in Environmental Matters (Aarhus Convention) of 1998 http://www.unece.org/fileadmin/DAM/env/pp/documents/cep43e.pdf (accessed 7 June 2016). See further J Bosek 'Implementing environmental rights in Kenya's new constitutional order: Prospects and potential challenges' (2014) 14 African Human Rights Law Journal 489498.

9 Bentley \& Calland (n 6 above) 342.

10 Bentley \& Calland 361. However, they do point out that this theory of change is subject to several caveats. First, intermediaries are necessary. Second, without an accessible and specialist enforcement mechanism, the right is unlikely to be widely claimed. Third, there is a need for government champions to champion the fight against a pervasive culture of secrecy. What is argued later in this article about problems regarding PAIA implementation confirms these caveats.

112009 (6) SA 323 (CC) para 63.

12 See South African Transport and Allied Workers Union \& Another $v$ Garvas \& Others 2013 (1) SA 83 (CC) (Garvas). 
their legitimate concerns. In the minority judgment in Garvas, Jaftha J held that '[i]t is through the exercise of the section 17 rights that civil society and other similar groups in our country are able to influence the political process, labour or business decisions and even matters of governance and service delivery'. ${ }^{13}$ As Woolman puts it, section 17 'vouchsafes a commitment to a form of democracy in which the will of the people is not always mediated by political parties and the elites that run them' ${ }^{14}$

\section{Theory: An outline of legislation governing the rights of access to information and to protest}

Although a full discussion of the regulatory systems governing access to information and protest in South Africa is beyond the reach of this article, it is necessary to give the broad strokes of each in order to contextualise the problematic implementation of these rights.

Section 32 of the South African Constitution contains quite a farreaching access to information right. ${ }^{15}$ It provides that everyone has a right of access to information held by the state, and to information held by private parties and which is required for the exercise or protection of any rights. ${ }^{16}$ PAIA came into effect in 2001, 17 in accordance with the directive in section 32(2) of the Constitution that national legislation be enacted to give effect to the right of access to information. The relationship between the constitutional right and PAIA is succinctly summed up by Hoexter, who explains that PAIA

13 Garvas (n 12 above) para 120.

14 S Woolman 'My tea party, your mob, our social contract: Freedom of assembly and the constitutional right to rebellion in Garvas $v$ SATAWU (Minister for Safety \& Security, Third Party) 2010 (6) SA 280 (WCC)' (2011) 27 South African Journal on Human Rights 346348.

15 Almost half of the world's countries - 98 at present - have enacted some form of access to Information law. Of these, only 19 countries have enacted laws which allow information to be requested from private parties. Of these, South Africa is the only country that appears not to qualify access to information from private bodies on the basis of some kind of relationship between the private body concerned and the state or the exercise of a public function. See M Siraj 'Exclusion of private sector from freedom of information laws: Implications from a human rights perspective' (2010) 2 Journal of Alternative Perspectives in the Social Sciences 211223 . See also T Mendel 'Freedom of Information: A comparative legal survey' UNESCO http://portal.unesco.org/ci/en/ev.php-URL_ID=26159\&URL_DO=DO_TO PIC\&URL_SECTION= 201.html (accessed 8 June 2016) 15.

16 The right to receive information is also recognised in art 9 of the African Charter, which is supplemented by the Declaration of Principles on Freedom of Expression in Africa adopted by the African Commission in 2002. Other regional instruments that emphasise the importance of access to information include the African Charter on Democracy, Elections and Governance; the African Union Convention on Preventing and Combating Corruption; the African Charter on the Values and Principles of Public Service and Administration; the African Youth Charter; the Protocol to the African Charter on Human and People's Rights on the Rights of Women in Africa; and the Model Law on Access to Information for Africa.

17 See Institute for Democracy in South Africa \& Others $v$ African National Congress \& Others 2005 (5) SA 39 (C) para 13. 
does not replace the constitutional right, but because it purports to 'give effect' to it, parties must now assert the right via PAIA. ${ }^{18}$

PAIA sets out the nuts and bolts of how to go about actually submitting or responding to a request for access to information. It provides for a request system; ${ }^{9}$ requires the designation of information officers to process requests for information; ${ }^{20}$ provides for the publication of a manual designed to make submitting requests easy to do; ${ }^{21}$ provides for time periods for responses to requests; ${ }^{22}$ and allows for partial redaction of confidential material ${ }^{23}$ and, in the case of requests to a public body, for an appeal mechanism. ${ }^{24}$ These are all features of an access to information system designed to pave the way for affordable, quick and hassle-free access to information by everyone living in South Africa.

The right to protest is also constitutionally protected in South Africa. ${ }^{25}$ Section 17 of the Constitution provides that '[e]veryone has the right, peacefully and unarmed, to assemble, to demonstrate, to picket, and to present petitions'. ${ }^{26}$ The legislative accompaniment to section 17 is the Gatherings Act, which came into operation in the dawn of South Africa's democracy as a product of the attempt by the Goldstone Commission of Inquiry to bring South Africa's assembly jurisprudence in line with international practice. ${ }^{27}$ The Preamble to the Gatherings Act recognises that '[e]very person has the right to assemble with other persons and to express his views on any matter freely in public and to enjoy the protection of the state while doing so', although this right is qualified by the duty to protest 'peacefully

18 C Hoexter The new constitutional and administrative law (2001) 57.

19 Secs 11, 18, 50 \& 53 PAIA.

20 Sec 17 PAIA.

21 Secs 10, 14 \& 51 PAIA.

22 Secs 20, 56 \& 57 PAIA.

23 Secs 28, 37, 59 \& 65 PAIA.

24 Sec 74 PAIA.

25 Art 11 of the African Charter also protects assembly rights. In 2014, the African Commission gave further content to this right in Resolution 281 on the Right to Peaceful Demonstrations.

26 This right is collectively referred to in this article as the right to protest.

27 M Memeza 'A critical review of the implementation of the Regulation of Gatherings Act 205 of 1993: A local government and civil society perspective' (2006) Report by Freedom of Expression Institute 12. The Gatherings Act is, therefore, not constitutionally-compelled legislation in the same way that PAIA is. Interestingly, there is some suggestion that the Gatherings Act was only ever intended to be used during the difficult transition into democracy around the time of the first democratic elections, and that the drafters of the Act understood that it was flawed, but saw it as a stopgap measure compiled in somewhat of a rush. See Freedom of Expression Institute (FXI) The right to protest: A handbook for protestors and police (2007) 5. 
and with due regard to the rights of others' ${ }^{28}$ This reflects the language of section 17.

The Gatherings Act defines what a public gathering is and outlines where, when and why a gathering can take place. It also introduces the main actors responsible for ensuring that gatherings in democratic South Africa occur peacefully. ${ }^{29}$ A 'gathering' is understood as 'any assembly, concourse or procession of more than 15 people on any public road ${ }^{30}$ or any other public place wholly or partly open to the air'. The purposes of a gathering can include criticising or promoting the policy or actions of any government, political party or political organisation; the handing over of petitions; and demonstrating either support for or opposition to, the policy or actions of any person or institution. ${ }^{31}$

The three main actors involved in protest procedures outlined in the Gatherings Act are the municipality, ${ }^{32}$ the police ${ }^{33}$ and the convener of the gathering. The convener is the leader of the gathering and is appointed by the person or organisation arranging the gathering to be the point of contact. ${ }^{34}$ Together, these three form the golden triangle supposedly responsible for negotiating the peaceful conduct of the protest.

For the purposes of this discussion, what is important is what the Gatherings Act provides for what should happen before a protest can occur lawfully. A convener must send a notification to the municipality of an intended gathering, using a standard form supposed to be available from all municipal offices. Notice must be given at least seven days before the planned gathering. ${ }^{35}$ On receipt of the notification, the municipality must, within 24 hours, call the convener to a meeting at which the logistics of the gathering are discussed with the South African Police Services (SAPS) and any other required service providers, such as paramedics. ${ }^{36}$ This meeting is often referred to as the 'section 4 meeting' or the 'triangle meeting' (referring to the three-way participation by the convener, the municipality and the SAPS). It is this triangle meeting which is the site

28 See S Murphy 'Unique in international human rights law: Article 20(2) and the right to resist in the African Charter on Human and Peoples' Rights' (2011) 11 African Human Rights Law Journal 474 for the discussion of a broader formulation of the right to resist in the African Charter.

'A municipality's role in the Regulation of Gatherings Act' Local Government Briefing Note 2012 (1) 1.

30 As defined in the Road Traffic Act 29 of 1989.

31 Including any government, administration or governmental institution.

32 Represented by an appointed 'responsible officer' or failing such appointment, by the chief executive officer (sec 2(4) Gatherings Act).

33 Also represented by an 'authorised member' (sec 2(2) Gatherings Act).

34 Sec 2(1) Gatherings Act.

35 There is certain information that must be included in the notice; see the helpful checklist and sample notice in FXI (n 27 above) 11-13.

36 If the municipality does not do so with 24 hours, the gathering is deemed legal and can proceed without any further formalities (secs $2,3 \& 4$ Gatherings Act). 
of contestation for communities across the country trying to organise lawful protests. This is discussed further below.

\section{Practice: Attempting to exercise the rights of access to information and to protest}

\subsection{Experience of communities and civil society}

Despite the existence of a progressive Constitution, as well as fairlydetailed legislation purporting to give effect to the rights of access to information and to protest, unfortunately both these rights remain outside the reach of most people living in South Africa. In fact, both PAIA and the Gatherings Act have proved to operate rather as an impediment to rights realisation than as a tool for providing effective access. $^{37}$

The civil society experience of using PAIA is characterised by requests for information being met with attitudes of extreme suspicion, very poor levels of understanding of PAIA, and a general disregard for the access to information rights of communities. This uphill struggle is captured in an annual report (PAIA CSN Shadow Report) published by the PAIA Civil Society Network (PAIA CSN), ${ }^{38}$ which documents civil society's collective experience in working with PAIA. ${ }^{39}$ In the 2014 PAIA CSN Shadow Report (which tracks requests submitted in the period August 2013 to July 2014), the results reveal that 56,8 per cent of all requests were either expressly refused or deemed to have been refused (because they were simply ignored). See the chart below for more detail. This is clear evidence that the legislation is not achieving its desired objective of fostering a culture of transparency.

37 D Cote \& J van Garderen 'Challenges to public interest litigation in South Africa: External and internal challenges to determining the public interest' (2011) 27 South African Journal on Human Rights 167172.

38 The PAIA CSN, established in 2008, is a collective of organisations committed to access to information and the realisation of a culture of openness and accountability.

39 These reports are available at http://www.saha.org.za/projects/national_paia_ civil_society_network.htm (accessed 7 June 2016). 


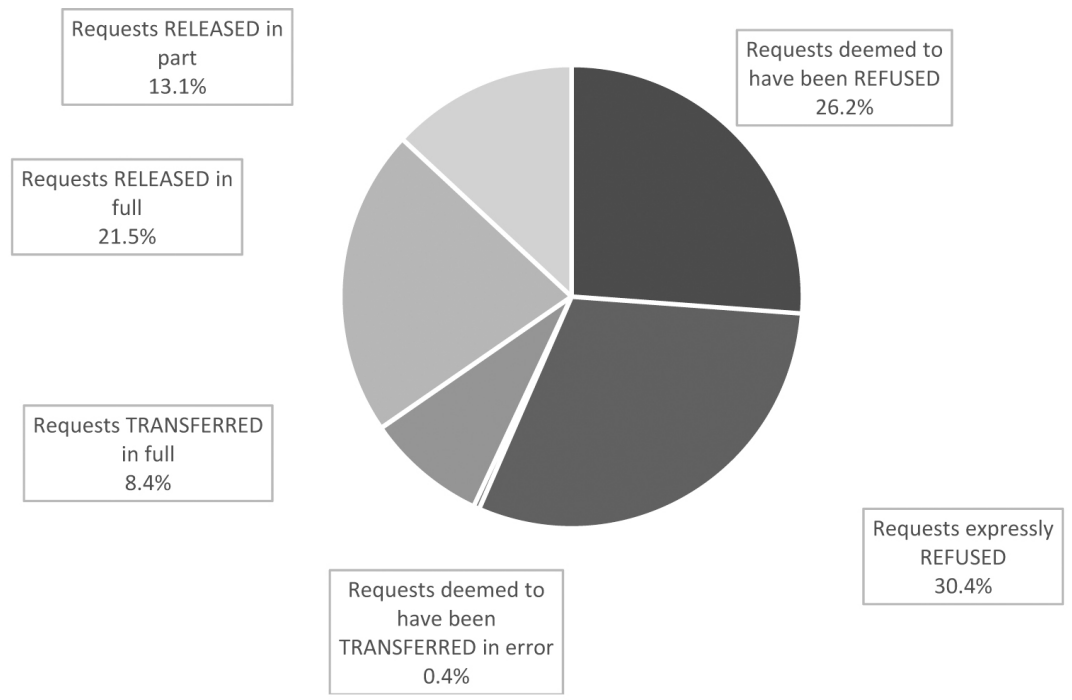

\section{CHART 2: Nature of responses to initial requests submitted to public bodies ${ }^{40}$}

Unfortunately, on the appeals front the story is not much better. In 2014, 58 internal appeals were submitted to 17 public bodies. ${ }^{41} \mathrm{~A}$ disturbing 44 per cent of appeals were ignored. Of those appeals that were responded to, 35 per cent were denied. ${ }^{42}$ These statistics do not reflect a society where access to information is a right and transparency is the default position. Rather, they demonstrate just how unlikely it is that the submission of a request for information will actually result in the release of information.

Another pattern emerging from the South African civil society experience is the use of inappropriate grounds for refusal by the state. This trend of relying on technical grounds for refusal to thwart access to information at a high cost to human rights is evident in MEC for Roads and Public Works, Eastern Cape \& Another $v$ Intertrade Two (Pty) $L_{t d}{ }^{43}$ In this case, an unsuccessful tenderer instituted review proceedings in order to obtain information relating to the adjudication of a tender for the repair and maintenance of hospital

402014 PAIA CSN Shadow Report 5.

412014 PAIA CSN Shadow Report (n 40 above) 7.

422014 PAIA CSN Shadow Report 2. The Report analyses a sample of 306 requests submitted by members of the PAIA CSN in that year; 260 of those requests were submitted to a total of 63 public bodies. 
equipment. The state took the technical point that section 7 of PAIA 44 precluded Intertrade from demanding additional documents before it had exhausted its procedural remedies under certain provisions of the Uniform Rules of Court. ${ }^{45}$ The court held: ${ }^{46}$

The appellants' resistance to Intertrade's request for documentation on technical grounds was ... most reprehensible ... Their response is rendered more deplorable by the report contained in the department's own correspondence which shows that, whilst they were embarking on delaying tactics at the taxpayer's expense, sick and vulnerable citizens were suffering and children were dying in poorly maintained hospitals.

Perhaps the most significant case relating to access to information in South Africa thus far is that which emerged out of the struggles of the Vaal Environmental Justice Alliance (VEJA) to obtain a document known as the Environmental Master Plan which mapped pollution levels caused by ArcelorMittal (AMSA), as well as the company's plan to remediate this damage over a 20-year period. VEJA sought access to the Master Plan in order to establish the extent to which their health problems and the threats to their livelihoods were being caused by AMSA, and also to assist them in playing a role in ensuring that AMSA complied with the pollution remediation measures outlined by the company itself. When other channels proved unsuccessful, VEJA in 2011 eventually resorted to submitting a request for the Master Plan in terms of PAIA. ${ }^{47}$

In November 2014, the Supreme Court of Appeal ordered AMSA to hand over the Master Plan. The Court made a number of critical findings in relation to AMSA's lack of good faith in its engagement with VEJA and the discrepancies between AMSA's shareholder communications and its actual conduct. ${ }^{48}$ The Court found that the regulatory framework applicable to the environmental sector envisaged a form of collaborative corporate governance in relation to

44 Sec 7 provides: '(1) This Act does not apply to a record of a public body or a private body if - (a) that record is requested for the purpose of criminal or civil proceedings; (b) so requested after the commencement of such criminal or civil proceedings, as the case may be; and (c) the production of or access to that record for the purpose referred to in paragraph (a) is provided for in any other law. (2) Any record obtained in a manner that contravenes subsection (1) is not admissible as evidence in the criminal or civil proceedings referred to in that subsection unless the exclusion of such record by the court in question would, in its opinion, be detrimental to the interests of justice.'

45 Rules $53 \& 35(12)$.

46 Intertrade (n 43 above) para 20. See also Garden Cities Inc $v$ City of Cape Town \& Another 2009 (6) SA 33 (WCC) para 24.

47 This case is the subject of a documentary produced by the Centre for Applied Legal Studies, the South African Human Rights Commission and One Way Up Productions, https://www.wits.ac.za/cals/about-us/law-and-film/ (accessed 7 June 2016).

48 For more information and discussion of this case, see http://cer.org.za (accessed 7 June 2016). 
the environment, based on the notion that environmental degradation affects everyone. ${ }^{49}$ The Court also emphasised the importance of corporate transparency in relation to environmental issues, stating that ${ }^{50}$

[c]orporations operating within our borders, whether local or international, must be left in no doubt that, in relation to the environment in circumstances such as those under discussion, there is no room for secrecy and that constitutional values will be enforced.

This judgment has correctly been hailed as an important vindication of the rights of access to information of communities, and clearly demonstrates the 'enabling' nature of the right to information. While it is of concern that it took VEJA about 15 years to actually get their hands on a full version of the Master Plan, justice has prevailed in the end, leaving a significant judicial precedent available for all who seek to advance transparency in South Africa.

Community experiences in trying to exercise the right to protest have been just as, if not more, frustrating as for those working in the access to information sector. The experience of the women of Marikana will be highlighted in order to demonstrate this. In August 2012, South Africa witnessed a degree of police brutality unprecedented in the democratic era, when 44 mine workers were killed during a strike on the platinum belt near the Lonmin mine at Marikana. In response, the women of the Marikana community decided to express themselves by organising a march to the local police station. They sought an end to police brutality in Marikana, the withdrawal of the army which had been deployed in the area, and a chance to express their grief at the death of their husbands, sons, lovers, fathers, brothers and friends. ${ }^{51}$ In the context of a discussion of protest as an enabling right, it is pertinent to mention that they also wanted to draw attention to longstanding and ongoing violations of their rights to housing, adequate water and electricity, and the absence of schools, medical facilities, sanitation, roads and other basic infrastructure in their communities. 52

However, all notices to the relevant municipalities were rejected with frivolous reasons provided, thus denying the women their right to protest. After attempting unsuccessfully to resolve the impasse through engagement with the local authorities, the women sought assistance from the Centre for Applied Legal Studies (CALS). ${ }^{53}$ Late into the night on 28 September 2012, CALS prevailed in an urgent

49 Company Secretary of ArcelorMittal South Africa \& Another $v$ Vaal Environmental Justice Alliance 2015 (1) SA 515 (SCA) para 71.

$50 \quad A M S A \vee V E J A$ (n 49 above) para 82.

51 'Woman's death in Marikana prompts march' SABC 22 September 2012 http:// www.sabc.co.za/news/a/57633c004ccf33729a3fdbb8fc2f576b/Womans-death-inMarikana-prompts-march-20120922 (accessed 7 June 2016).

52 Not unlike an expression of the activist-held understanding of 'security' discussed in IT Sampson 'The right to demonstrate in a democracy: An evaluation of public order policing in Nigeria' (2010) 10 African Human Rights Law Journal 432434. 
application in the North West High Court. The court order set aside the municipalities' decision to prohibit the march, recognised the women's rights and allowed the march to proceed. ${ }^{54}$

Unfortunately, the struggles of the women of Marikana to peacefully exercise their rights to protest did not end there. When in 2014 they again sought to hold a march, they again met with hostility and obstruction from the local authorities. This took the form, for example, of the two municipalities involved attempting to delay the holding of the triangle meeting by bouncing responsibility between them, claiming that notice had been served on the incorrect municipality. This time the women sought to gather on 21 March 2014 (Human Rights Day in South Africa) in an attempt to support mine workers in their community who were at the time engaged in a protracted strike against exploitative wages in the South African platinum sector. Again, it was unfortunately only due to the intervention by lawyers that the women of Marikana were able to proceed with their attempts to protest lawfully and peacefully.

Although this is a single story of one community struggling to exercise their constitutional right to protest, it is a common one. In South Africa, both the frequency and severity of protests have in recent years been steadily on the rise. Statistics on protests in South Africa abound. According to one source, in 2006 there were 11000 protests in South Africa which translates to about 30 protests per day. ${ }^{55}$ Another source has the figure of the average number of protests per month increasing from 8,7 in 2007 to 16,3 in $2010 .^{56}$ Yet another presents a picture in which South Africa experienced an average of 8,73 protests per month in $2007,9,83$ protests per month in 2008 , rising to 17,75 in 2009 and tapering down to 8,8 during the first five months of 2011. In 2014, researchers at the Social Change Research Unit at the University of Johannesburg released the results of a study drawing on over 250 interviews and covering more than

53 CALS is a human rights organisation based at the Wits Law School which engages in research, advocacy and impact litigation across its five programmes: Basic Services; Business and Human Rights; Environmental Justice; and Gender and Rule of Law. More information on CALS may be found at https://www.wits.ac.za/cals/.

54 CALS media release of 28 September 2012 drafted by Kathleen Hardy. See also 'Marikana's women win right to march' City Press 29 September 2012 http:// www.news24.com/Archives/City-Press/Marikanas-women-win-right-to-march20150429 (accessed 7 June 2016).

$55 \quad \mathrm{FXI}$ (n 27 above) 4.

56 J Hirsh 'Community protests in South Africa: Trends, analysis and explanations' (2010) Community Law Centre, Local Government Working Paper Series 1 in C Mbazira 'Service delivery protests, struggle for rights and the failure of local democracy in South Africa and Uganda: Parallels and divergences' (2013) 29 South African Journal on Human Rights 251266. 
2000 protests since 2004. The results track a general rise in protest action since 2004, with peaks in 2009 and 2013.57 What is clear is that the system designed by the Gatherings Act is not working in practice.

\subsection{Similarities in problematic implementation}

The primary purpose of the article is to draw on lessons from practice in order to highlight the very similar ways in which the realisation of access to information and protest rights are being thwarted. The next section identifies some of these parallels.

\subsubsection{Legislation deliberately or incompetently misinterpreted}

The first and probably most significant similarity relates to the role of government officials in the interpretation of legislation. Both PAIA and the Gatherings Act are misunderstood - or deliberately improperly applied - by government officials tasked with implementing them. In relation to the Gatherings Act, municipal officials routinely operate on the basis that the conveners of a protest are required by the Gatherings Act to ask for permission to protest when this is in fact not the case. The requirement is notification, not consent. The Gatherings Act requires municipalities to be involved in the administration of the right to protest but not in providing consent. Local officials thus substitute an obligation to facilitate protest with a right to veto. As emphasised in the Local Government Briefing Note, '[t] he notice of a gathering should not be seen as an "application". Municipalities may, in principle, not refuse gatherings to take place. ${ }^{58}$

The legal position is that the only grounds on which a protest can lawfully be prevented by the municipality before the protest has commenced is if less than 48 hours' notice is given ${ }^{59}$ or if the gathering poses a threat of injury to participants or others, of extensive damage to property or of serious disruption of traffic and SAPS is not equipped to contain that threat. ${ }^{60}$ Even then, a reasonable suspicion of violence is not sufficient. There must be credible information submitted under oath in an affidavit. Importantly, neither the purpose of the protest, nor past indiscretions by the group organising it are relevant considerations. The validity of a prohibition thus stands or falls on the ability of SAPS to provide security.

In addition, if the municipality suspects that a gathering may need to be prohibited, the triangle meeting must still occur in good faith in

57 'No quick fix for protests study' Polity.org.za 12 February 2014 http:// www.polity.org.za/article/ni-quick-fix-for-protests-study-2014-02-12 (accessed 7 June 2016).

58 Local Government Briefing Note (n 29 above) 3.

59 Even then, prohibition is discretionary and not mandatory; see the language of 'may' in Gatherings Act sec 3(2).

60 Sec 5(2) Gatherings Act. Note that there are further sections allowing police officers to disperse a gathering once it is already in progress, but these are beyond the scope of this discussion. 
order to explore whether any solutions exist. If after all this there is still no way of ensuring adequate containment of the credible threat supported by evidence on oath, reasons must be provided for the prohibition. ${ }^{61}$ Notwithstanding this extremely high threshold outlined in the law, currently a community or social movement seeking to protest lawfully by going through the process set out in the Gatherings Act should steel themselves for the likelihood that they will be rebuffed and obstructed by either the municipality or the police, or both. 62

In Garvas, 63 the Constitutional Court upheld the validity of provisions of the Gatherings Act which impose (at least partial) liability for damage caused to property during a gathering on the conveners of the gathering unless they took all reasonable steps to avoid the damage and did not reasonably foresee the damage. Importantly, on the topic at hand, the Court in Garvas seems to indicate that the Gatherings Act envisages a process of notification and administration of logistics, not permission-seeking. ${ }^{64}$

Similar misinterpretation problems are occurring in the context of access to information, where state officials administering PAIA erroneously demand that requesters of information held by a public body should justify why they seek such information. PAIA requires no such justification. While requestors seeking information from a private entity must explain which right they seek to exercise or protect by obtaining the information sought, there is no such requirement when asking a state entity for information.

The justification for this distinction is that information in public hands is, after all, the public's information and should, therefore, be easily and publicly accessible as the default position. ${ }^{65}$ In fact, PAIA reinforces the idea that the right of access to information from a public body is an unqualified one when it expressly stipulates in section 11(3) that any reasons for the request given by a requester, or whatever the information officer may suspect are the reasons for the request, do not affect the right of access to information from a public body.

61 Local Government Briefing Note (n 29 above) 3.

62 There is a groundswell of writing on this phenomenon. See eg Memeza (n 27 above); $M$ Johnson \& J Griffith 'Controlling gatherings - Great in theory' (June 2012) Without Prejudice 77; R2K Activists Guide 'Protesting your rights: The Regulation of Gatherings Act, arrests and court processes' http://www.r2k.org.za/ wp-content/uploads/gatheringsGuide_WEB.pdf (accessed 7 June 2016); Woolman (n 14 above) 349; and various publications by Duncan who has written extensively on the subject; see eg J Duncan The rise of the securocrats: The case of South Africa (2014).

63 Garvas (n 12 above).

64 This reading of the judgment is supported by Johnson and Griffiths. See M Johnson \& J Griffiths 'The Regulation of Gatherings Act 205 of 1993' Legal City online magazine 27 July 2012 http://www.legalcity.net/Index.cfm?fuseaction =magazine. article\&ArticlelD=4493411 (accessed 7 June 2016).

65 I Currie \& J Klaaren The Promotion of Access to Information Act commentary (2002) 1721. 
These interpretation problems in the context of both protest and access to information must be understood in light of section 39(2) of the Constitution, which requires courts to promote the spirit, purport and objects of the Bill of Rights when interpreting any legislation. While this interpretive obligation applies specifically to courts, the spirit of the Bill of Rights would seem to require state officials to do the same, given that the Constitution is the supreme law in South Africa. 66

In summary, the exercise of the constitutional right to protest does not require permission and the exercise of the constitutional right of access to information from state bodies does not require justification. In both contexts, officials are either demonstrating a pervasive misreading of the legislation or there is a more sinister, deliberate 'misunderstanding' at play. In both cases, the purpose of the legislation is to spell out the nuts and bolts of the process of making the right a reality. Yet, the way in which it is being administered in practice is having the opposite effect: Rather than facilitating the rights in question, the processes are used to impede these rights.

\subsubsection{Delay and double standards}

The second similarity in the disturbing implementation of PAIA and the Gatherings Act is that requests for information and gathering notifications are routinely ignored or left to the very last minute before a response is given. For instance, the 2014 PAIA CSN Shadow Report reflects that only 37 per cent of PAIA requests and 19 per cent of PAIA appeals were responded to within the prescribed deadline. ${ }^{67}$ The impact of non-compliance with statutory timeframes has a debilitating effect on the rights holder when, as is the case here, their recourse is litigation. Litigation is costly, slow, intimidating and requires access to legal representation. These difficulties relating to access to justice are particularly acute for the kind of communities who are likely to be seeking to protest or to access information in the first place.

In addition to the severe impact of non-compliance by the state (or the private sector), there are also double standards about the repercussions of non-compliance. The Gatherings Act imposes criminal sanctions on the convener of a gathering who fails to comply with the procedural requirements set out in the Act. ${ }^{68}$ Post-Garvas, there is also the spectre of liability for damages caused by other people involved in the protest. The criminal sanctions and liability for damages faced by the conveners of a gathering must be compared to the consequences for municipal officials who merely ignore protest

66 Sec 2 of the Constitution provides that '[t]his Constitution is the supreme law of the Republic; law or conduct inconsistent with it is invalid, and the obligations imposed by it must be fulfilled'.

672014 PAIA CSN Shadow Report (n 40 above) 3.

68 Attracting a possible penalty of a fine up to R20 000 or imprisonment of one year, or both. 
notifications or are deliberately obstructive in trying to avert the holding of a triangle meeting. What are the consequences for such officials? Typically, absolutely nothing. The same is true in the context of access to information. If an information officer ignores a PAIA request and the prescribed period for response elapses, it is treated as a deemed refusal of the request. ${ }^{69}$ That means that the requester then has to lodge an internal appeal against the deemed refusal (assuming the request is to a public body). ${ }^{70}$ In practice, there seems to be a disturbing trend of information officers routinely ignoring the initial request and appeal being the first time PAIA requests are dealt with.

Therefore, the picture looks something like this: If the convenor of a march does not comply with the Gatherings Act, they risk a criminal record; if a local authority tries to enforce unlawful requirements (such as confirmation of the attendance of the person to whom the protestors would like to hand a petition), it is unlikely that there will be any personal consequences. Instead, the convenors will find it more difficult to hold the protest. If a requester of information submits an improper request under PAIA, they do not obtain the information, but if an information officer ignores a proper request, the requester still does not get the information. In sum, whoever is in the wrong, communities lose. The kinds of communities seeking both to protest and to access information in order to realise their rights are typically poor, vulnerable and marginalised. The current system, therefore, skews power heavily in favour of the state and runs the risk of criminalising the poor. ${ }^{71}$

\subsubsection{Need for legal assistance}

The third point of resonance in the experience of those seeking to realise their rights of access to information and to protest is the unfortunate need for legal assistance. In both contexts, the processes have been constructed in such a way that the chances of realising these rights are considerably increased by the presence of an

69 PAIA secs 27 (public bodies) \& 58 (private bodies).

70 There is no internal appeal mechanism for information requests to private bodies.

71 Encouragingly, there are moves afoot to shift this power imbalance. The Social Justice Coalition, a social movement based in Cape Town which campaigns for safe, healthy and dignified communities, is currently involved in ongoing litigation (in which they are represented by the Legal Resources Centre) challenging the constitutionality of sec 12(1)(a) of the Gatherings Act. See 'Trial of SJC-21 continues' 6 October 2014 http://www.sjc.org.za/posts/trial-of-sjc-21-continues (accessed 7 June 2016); 'GroundUp: Convicted activists vow to challenge gatherings law' Daily Maverick 12 February 2015 http://www.dailymaverick.co.za/ article/2015-02-12-54dbde4ce32fd/\#.VfEyCClaJrQ (accessed 7 June 2016); 'How constitutional are the regulations on public gatherings?' GroundUp 17 July 2015 http://groundup.org.za/article/how-constitutional-are-regulations-public-gatherin gs 3133\#sthash.HhwFrev5.dpuf (accessed 7 June 2016). A similar case is also being litigated by a group of 94 healthcare workers - represented by Section 27 who were detained and charged after holding a peaceful overnight vigil objecting to job losses. See http://www.dailymaverick.co.za/article/2015-10-05-rightsgroups-take-on-law-after-free-state-healthcare-workers-conviction/\#.V1ZyeuJ97IU (accessed 7 June 2016). 
intermediary. In the experience of CALS, communities are far more likely to be able to stage a lawful protest if there is a lawyer present at the triangle meetings discussed above. Likewise, lawyerly follow-up to an access to information request also significantly increases the chances that the request is taken seriously.

Unfortunately, the need for legal assistance plays out not only in the preparation for a protest or a request for access to information, but also should it become necessary to challenge a decision. In the protest context, if a march is blocked by local authorities, one's recourse is to approach a court for urgent relief within 24 hours. Similarly, if both a PAIA request and internal appeal are denied, the only remedy is to approach the courts. While in theory it should be possible to do so without the assistance of a lawyer, in reality courtrooms and legal processes remain inaccessible and intimidating in South Africa. This intermediary problem is not unique to access to information or protest, but for a country which has for 21 years been committed to access to justice, it is a disquieting reality that is slowly suffocating the realisation of rights.

Fortunately, this problem may soon be somewhat mitigated, at least in relation to access to information. For several years, civil society activists have been calling for some kind of information ombud to make accessing information a quicker, cheaper and generally more accessible process. ${ }^{72}$ Although the South African Human Rights Commission has up to now had a mandate in relation to access to information, this is not its only or even its primary role, with the result that it has tended to confine itself to promoting knowledge about PAIA rather than acting as its watchdog. ${ }^{73}$ The Protection of Personal Information Act 4 of 2013 has now introduced an Information Regulator which will have jurisdiction to hear appeals against unsuccessful PAIA requests. ${ }^{74}$ The Regulator is currently in the process of being established. Interviews have been conducted and a recommended list of appointments was handed to the National Assembly in May 2016. Hopefully, the Information Regulator will operate in such a way that communities are able to challenge attempts by either government or the private sector to block access to information, without the need for assistance from a lawyer.

\subsubsection{Interplay between state and private entities}

The last parallel to be drawn between the implementation of PAIA and the Gatherings Act relates to the way in which the state and private sector play 'tag team' in their attempts to avoid accountability. In the access to information context, state officials often use the third party

72 Particularly in relation to requests or information from private bodies as there is no internal appeal mechanism against refusals of such requests, which means that litigation is the only recourse.

73 Bentley \& Calland (n 6 above) 359.

74 See ch 5 of that Act. 
notification mechanism ${ }^{75}$ to delay having to make a decision on an information request, hiding behind the cloak of supposed responsible handling of information. If the same request for information is made to the company concerned, the response is often that the information sought is held by the state and should be requested from them. The Centre for Environmental Rights ${ }^{76}$ has done valuable work in documenting the civil society experience of using PAIA in particularly the environmental sector. ${ }^{77}$ They confirm that both private and public bodies refer requesters to each other (particularly in the environmental sector when the information sought relates to permission and authorisation and is, therefore, held by both private and public bodies).

It is important to contextualise what this kind of delay may mean, as there is often time sensitivity in the need for information. Consider, for example, a community seeking information about levels of pollution and other environmental harm. If the PAIA requests are stalled for too long, the harm may well occur before the PAIA process is resolved. In the environmental context, there is often a window in which damage to the environment (and thereby to people's health and livelihoods) can be prevented. After that window closes, mitigating the extent of the damage is the best one can do. Timing is thus critical. No doubt, there are many examples from different sectors as to why accessing information is time-sensitive. This is not merely a technical matter of legal process.

This 'tag team' strategy was also evident in the Marikana women's march discussed above. In the 2014 protest, the women sought to march along a road on property owned by mining company Lonmin. One of the ways in which the municipality sought to obstruct the march was to take the position that the women would need permission from Lonmin to proceed. By sending communities with limited access to resources from pillar to post in this way, access to justice is further undermined in a country supposedly committed to making human rights a reality. Furthermore, while PAIA includes third party notifications in its envisaged regulation, the Gatherings Act provides scant guidance as to how to manage the inclusion of a private company in protest action.

75 In instances where an information officer receives a request which implicates a third party, according to sec 47 of PAIA, she must notify the third party of the existence of the request and give them 21 days to either consent to the release of the information or to make representations on the issue.

76 The Centre for Environmental Rights is a civil society organisation working in the environmental justice sector to provide legal and related support to environmental CSOs and communities. See further http://cer.org.za/ (accessed 7 June 2016).

77 The Centre for Environmental Rights has published several reports in respect of transparency and PAIA. These reports can be found at http://cer.org.za/ programmes/transparency (accessed 7 June 2016). 


\section{The way forward}

So what should be done about these disturbing trends in attempts to realise enabling rights such as rights of access to information and to protest? The article does not presume to present comprehensive answers (as it is primarily about analysing the nature of the problem), but a few ideas are offered for further discussion. First, given the similarities between attempts to protest and to access information described above, it should be considered whether there are systemic trends emerging in relation to 'enabling rights'. Is the nature of the difficulties in implementation similar in relation to other enabling rights in South Africa, or to the implementation of protest and access to information rights elsewhere in Africa, in a way which may point to a more systemic picture?

Second, to the extent that they do not do so already, civil society organisations and communities working on rights-based issues (whatever their focus) need to incorporate into their work a focus on enabling rights and develop expertise in these areas. This kind of intersectionality is required to enhance the possible impact of rightsbased work.

Third, the executive needs to ensure that all officials responsible for administering PAIA and the Gatherings Act - primarily located in local government - fully understand the provisions of these laws. ${ }^{78}$ Perhaps there is room for exploring a provincial or national oversight role in these areas.

Lastly, as the office of the Information Regulator is established in South Africa, government, the private sector and civil society alike need to support the operation of this office in the hope that it may remove the need for lawyers and, hence, make access to information a more user-friendly process.

\section{Conclusion}

South Africa is blessed with a progressive Bill of Rights containing a far-reaching right of access to information, as well as a right to protest. These rights are given flesh by PAIA and the Gatherings Act respectively. Fundamentally, laws about access to information and protest have the potential to make a difference to the lives of those living in poverty by shifting the power balances between communities and the state or private sector. Twenty-two years into democracy, neither PAIA nor the Gatherings Act is living up to this promise. We

78 Fuo has highlighted the way in which the design of the South African constitutional system puts local government at the forefront of the social justice project. See O Fuo 'Public participation in decentralised governments in Africa: Making ambitious constitutional guarantees more responsive' (2015) 15 African Human Rights Law Journal 167. 
cannot afford to rest on the laurels of a progressive system in theory, and must confront the pervasive implementation problems occurring in practice.

The way in which both PAIA and the Gatherings Act are being implemented often impedes rather than promotes the rights concerned. The impediments in these two contexts (access to information and protest) are playing out in strikingly similar ways. The article has discussed four such similarities: misinterpretation of legislative provisions by government officials; delay and double standards; the continuing need for assistance from legal intermediaries; and the game of tag played by the state and the private sector.

If the implementation of this legislation is impeding the realisation of rights, and we understand these rights as enabling rights that hold the key to the realisation of an array of other constitutional rights, then the implementation failures have consequences beyond just the spaces of protest and access to information. Despite the potential of laws such as these, 'the prospect that they might make a meaningful contribution to a re-alignment of power relations may falter against the rock of weak implementation'. ${ }^{\prime 9}$ The existence of such striking similarities in relation to protest and access to information may well point to the more systemic problem of civil and political rights failing to enable the realisation of socio-economic rights. The failure to realise the rights to protest and to access information undermines the ability to achieve the South African constitutional vision of a society based on dignity, equality and freedom, and strikes at the very heart of the ability to make democracy work.

$79 \mathrm{R}$ Calland 'Turning right to information law into a living reality: Access to information and the imperative of effective implementation' (2003) publication of the Open Democracy Advice Centre 2 quoting Andrew Puddephatt, Executive Director of ARTICLE 197. 